\title{
ガラスの応カ緩和現象
}

\author{
北野 一 郎 \\ （神戸工業株式会社真空管技術部）
}

\section{On the Stress Relaxation Phenomenon in Glass}

By Ichiro KITANO

(Kobe Kogyo Corp.)

\section{1.まえがき}

高温から急冷したガラス内の秷を, 一定温度で除去 する場合の緩和過程については, 従来多くの研究者に よつてとりあげられているが, 中でも Taylor2)はい わゆる Maxwell。過程3) と Adams-Williamson 過 程4)とを分子的な立場から考察し, 解離会合の概念を 採用することによつて，極めて合理的な除画法則を確 立した。最近この方面に Eyring の Rate Process Theory5)を適用することが試みられ，森谷・佐藤6) はピストンとバネをるつ Maxwell 型要素の並列体模 型を組合せることによつて, 除歪現象を模型的に説明 された。筆者は Taylor の理論に Eyríng の絶対庈 応速度論》を適用儿, Maxwel1 過程 とAdamsWilliamson 過程とをそれぞれ異るポテンシアル障壁 に対応せしめ，両過程に対する活性化エネルギ，すな わち障壁の高さを実験的に算出して見た。

\section{2. 急冷ガラスの特性}

急冷されたガラスは, 各温度に特有の状態を実現す る㗇なく, 高温からの状態か廭分され凍結された儘に なつているので, 徐冷ガラスに比しその網目組織すあ る程度抎げられた儘になつて扔り, 構造単位自身るこ まかい。又, 種々の物理的性質, 例光ば会合度, 配位 数, 比容積等も異なつている。いま, 解離と会合とが 平衡にない急冷ガラス内では, 不飽和に解離したイオ ン種には霆がかうつて扔り,この歪はこれら解離単位 が集合体文は会合体を作ると緩和されるすのと，仮定 すると, 元来対称であるべきポテンシアルエネルギ曲 線は, 個々の不飽和解離単位にかつつている歪の為に Fig. 1 のよりに非対称となり, 始原系にある各解離 単位は备部熱エネルギを得て障壁を越え, 対称性を恢 復しようとする傾向を持つ。従つてこのような性質は 急冷ガラスの chemical な特性に対応するものであ る。

次に急冷の際に入る内外の温度分布によつて張力と 压力が入り,この内部応力は各結合手に特殊のポテン シアルエネルギを与文, 各解離体を多少とも平行に强
制配列せしめる。この模型ば非対称ポテンシアル障壁 の非詨称性をますます増大せしめる Fig. 2 によつて 示され，この過程は急冷ガラ゙スの mechanical な特 ・性に対応していると考えることができる。

\section{Rate Process としての除歪過程}

急冷ガラス内の雷が一定温度で緩和される過程を Rate Process として取扱つて見よう。

(1) Mechanical Process この過程は, 各構 造単位之解離体の強制配列を解く過程で, 前述のよ5 に不飽和解離体は更に chemical な歪を持つている ので，そのポテンシアル障壁は非対称であり，且つそ の非対称性は強制配列により更に大きくなつている。 (Fig. 2)

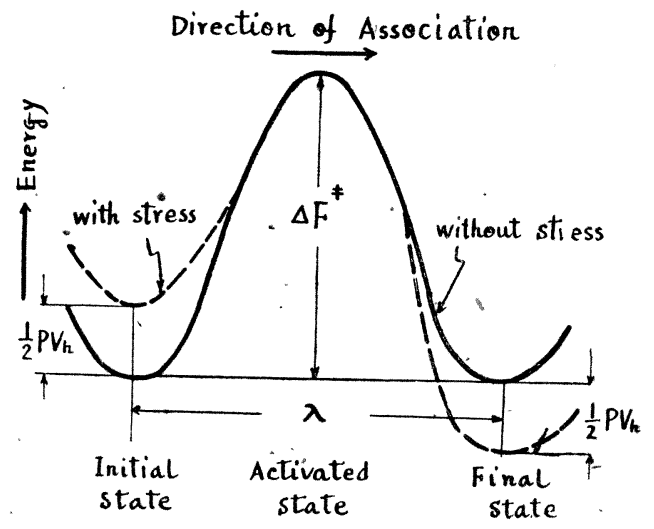

Fig. 1 Symmetrical Potential Energy Barrier for the Chemical Process in Annealing.

一ゲの分子種が障壁を越えて再配列を行ら場合の速 度恒数は，移送係数を 1 とすれば次式で与えられる。 forward : $K_{f}=K_{1} e^{\gamma P V_{h} / k T}$

reverse : $K_{r}=K_{2} e^{-(1-\gamma) P V_{h} / K T}$

但し

$$
\begin{aligned}
& K_{1}=\frac{k T}{h} e^{-\Delta F_{1} * / R T} . \\
& K_{2}=\frac{k T}{h} e^{-\Delta F_{2} * / R T},
\end{aligned}
$$

こつで $P$ は内部応力, $\gamma$ は対称係数, $V_{\hbar}$ は運動 


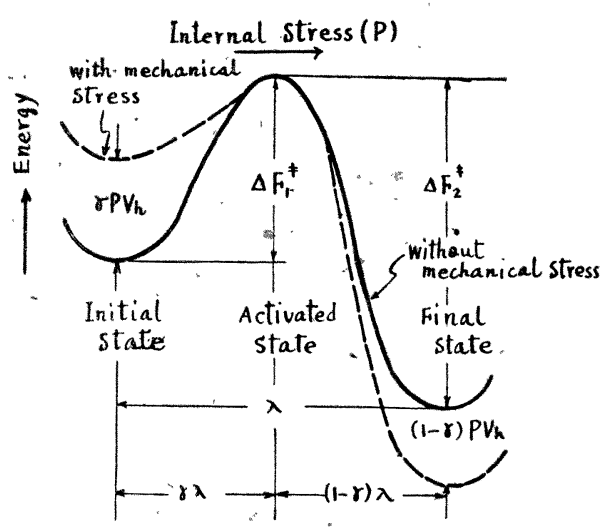

Fig. 2 Unsymmetrical Potential Energy Barrier for the Mechanical Process in Annealing.

体単位の断面積とその単位体の動く距離を掛合した積 で,従つて $r P V_{h}$ は単位体が始原系から終局系に向つ て移動寸る間に $P$ によつてなされる仕事の中，始原 系と活性状態との閐になされる仕事の割合を表す。 $\Delta F_{1}^{*}, \Delta F_{2}^{*}$ は Fig. 2 の非対称ポテンシアル障壁の 高さ（活性状態に対寸る $1 \mathrm{~mol}$ 当りの自由エネルギ 差), $k$ は Bolzmáann 定数, $h$ は Planck 定数, $R$ は ガス定数; $T$ は絶対温度で, $k T / h$ は $300^{\circ} \mathrm{K}$ で約 $6 \times$ $10^{12}$ なる值を持つ脈動数である。

一ケの単位体が単位時閒に障壁を越える回数は $K_{r}$ 一 $K_{r}$ であつて，いま内部応力 $P$ はその単位体の数 $N$ に比例するものと仮定すれば $f=a N$ ( $a$ は定数) と書表わすことができ，又単位体が障壁を越えて再配 列老行う速度は

$$
\frac{-d N}{d t}=N\left(K_{f}-K_{r}\right)
$$

で与えられる。

障壁の非対称が著しいから $K_{f} \gg K_{r}$. である。 従つて上式で $K_{r}$ をを無視すると結肩

$$
\frac{-d p}{d t}=P \cdot K_{1} e^{r P V_{h} / k T}
$$

を得る。更に一般には $\gamma P V_{n} / k T \ll 1$ であるから は更に簡単になり

$$
\frac{-d p}{d t}=K_{1} P
$$

を得る。この式は周知の Maxwell 式に外ならない。 実験によつて各温度に怙ける $K_{1}$ 方得られたならば, この過程に対する活性化自由エネルギは (3)より

$$
\log \left(K_{1} / T\right)=\log (k / h)-(1 / T)\left(\triangle F_{1}^{*} / 2.3 R\right)
$$

から計算できる。

(2) Chemical Process この過程は平行配列 を解かれた不飽和解離単位がポテンシアル障壁を越し て会合し，その温度に特有な平衡状態を再現すること により歪の緩和を行ら過程である。対称ポテンシアル であるから前式に括いて $K_{1}=K_{2} \equiv K, \gamma=1 / 2$ として
次式を得る。

$$
\begin{aligned}
\frac{-d P}{d t} & =P K\left[e^{P V_{h} / 2 k T}-e^{-P V_{h} / 2 k T}\right] \\
& =2 P K \sin \mathrm{h}\left(P V_{h} / 2 k T\right) \ldots \ldots .
\end{aligned}
$$

(9) の正確な解は Cagle, Eyring8) によつて解か れでいるけれども，一般には $P V_{h} / 2 k T \ll 1$ であるか ら $\sin \mathrm{h}\left(P V_{h} / 2 k T\right)=P V_{n} / 2 k T$ とすることができ

$$
\frac{-d P}{d t}=P^{2} \cdot \frac{K V_{n}}{k T}
$$

この式は良く知れた Adams-Williamson 式に対応す るもので, 各解離単位が互に相協力して $\Delta F^{*}$ なる対 称ポテンシアルを越えて会合を行う chemical な過 程である。実験によつて Adams-Williamson 式の速 度恒数 $K^{\prime}$ カ浗まると

$$
K^{\prime}=\frac{V_{h}}{k T} \cdot K=\frac{V_{h}}{h} e^{-\Delta r * / k T}
$$

徉つて

$$
\log K^{\prime}=\log \left(V_{h} / h\right)-(1 / T)\left(\Delta F^{*} / 2 \cdot 3 R\right)
$$

より会合過程に指ける障壁の高さを計算することがで きる。

\section{4. 実 煥}

実験は氷晶楔字併用せる光弾性装置を用い, 試料中 の歪によつて呈される birefringence が, 一定温度 て時間と共に減小寸る過程を観測記録することによつ. て行われる。

（1）実験試料 直接温度の高い儘で観测を行5 のであるから, 試料は两面が平行でなくてはならな い。簡単の為に断面が $1 \mathrm{~cm} \times 1 \mathrm{~cm}$ の角柱試料を用 い, 長さは約 $7 \mathrm{~cm}$ にきりとる。

これを $560^{\circ} \mathrm{C}$ から放冷すると内部に張力, 外部に 王力と著しい内部応力が残留する。実験に供したガラ スは受信管, 電球等のバルブに使用されるるつとも普 通のソーダガラスである。

(2) Birefringence Fig. 3 で, 点 $x$ におい. て観測される birefringence $\phi(x)$ は

$$
\phi(x)=B \int_{-a}^{a}\left\{P_{z}(x, y)-P_{x}(x, y)\right\} d y
$$

$B$ は光弾性常数である。写真上で見られる縞变位 $\boldsymbol{F}^{*}$ （x）は，水晶楔の相隣る平行縞間隔を $h$ とし，写真 払大率を $m$, 光源波長を $\lambda$ とすると $F(x)=\phi(x) h / m \lambda$ : なる関係にあるから， $F(x)$ は常に $z, x$ 両方向の主. 応力差に比例して表れる。 $F(x)$ を測定して $P_{z}, P_{x}$ をそれぞれ分離して求めることは煩雑であるから，自 由周辺 $x=a$ に持ける变位は $P_{z}$ のみによることを利 用すると

$$
\bar{F}(1)=\frac{2 h B}{m \lambda} \int_{0}^{1} P_{z}(1, \bar{y}) d \bar{y}
$$


こつで $\bar{x}=x / a, \bar{y}=y / a, \bar{F}(1)=\{F(x / a) / a\}_{x=a}$ なる無 次元で表わす。いま，ガラスは温度 $\theta_{s}$ 以上では歪は 現われず $\theta_{s}$ 以下で弾性的に応力が発生するすのと仮 定すると, 各点の応力は中心が $\theta_{s}$ になつた時その点 と中心との温度差に比例することになる。周辺 $\bar{x}=1$ り各点について, この温度差を熱层導方程式から解い て求めると抛物線分布をなすことが知礼るので, 従つ 応力分布为

$$
P_{z}(1, \bar{y})=P_{z}(1,0)\left(1+\alpha \bar{y}^{2}\right)
$$

と表わせる。これを（15）に入れると

$$
\bar{F}(1)=\frac{2 h B}{m \lambda}(1+\alpha / 3) P_{z}(1,0)
$$

Fig. 4 に $B=2.43 \mathrm{~m} \mu / \mathrm{cm} \cdot \mathrm{kg} / \mathrm{cm}^{2}, h=1.3 \mathrm{~cm}, m=$ 1.5, $\alpha=0.4 \sim 1.0$ の場合の数做計算を示す。このよ

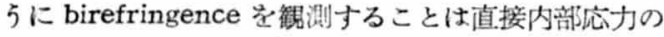
緩和現象を追跡することに対応寸る。

（3）実験結果 $560^{\circ} \mathrm{C}$ 上り放冷した試料を， 440 〜 480 C の温度に保つた驴中に投じてその除雷過程を 観測すると，時聞の経過と共に歪は Fig. 5 の写真に 示すように減少してりく。室温より上記設定温度に急

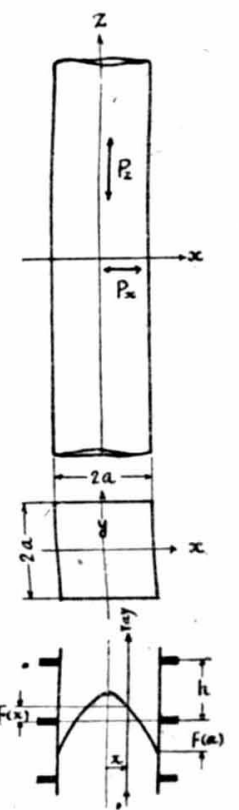

Fig. 3 Test Piece and its Birefringence.
熱すると，加熱操作による雷が 著しく重畳するから，この影瑟 をできるだけ小さくする為， らかじめ試料は $330^{\circ} \mathrm{C}$ に加熱 しておく(残留応力はこの温度 では影響されない。試料を $330^{\circ} \mathrm{C}$ から該都定温度に急熱し た後, 加熱操作による一時霆が 消隇し, 且つ既存歪与士たその 温度で一部綬和されてゆき， $\vec{F}(1)=1$ となる時を $t=0$ とす る

Fig. 6 に実験結果を示す。

（4）実駼結果の解析 Fig 6 に見るように，歪が大きい とその緩和は急速に進行するが 時間が充分経過した後は非常に 絈漫となる。いまこの二つの 過程につきそれぞれ考察して見 よ5。

(i) Chemical Process

間が充分経過すると，不館和解離体の平行配列が解か れ，これら解陮体が Fig. 1 のボテンシアル障壁を越 え，相互に会合することによつて小さな䨍が緩和され る。

この過程は前述の (11) 式に従うごとが Fig. 7 に よつて示され，反応速度恒数 $K^{\prime}$ の温度依存性が Fig. 8 のようになるから，(13) 式より対称ボテンシ

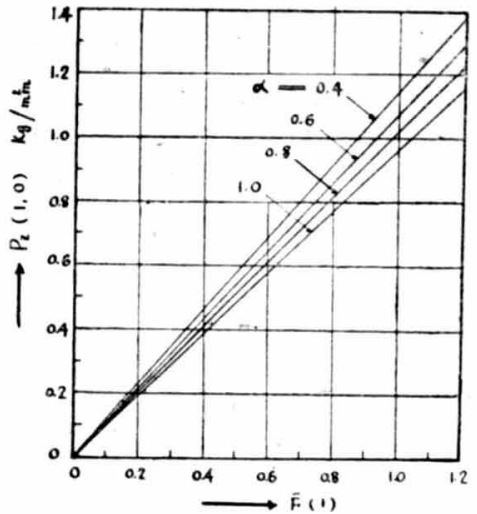

Fig. 4 Relation between Birefringence $\bar{F}(1)$ at $x / a=1$ and Stress $P_{z}(1,0)$ at $x / a=1, y / a=0$.

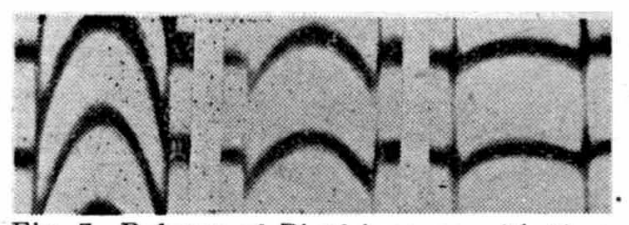

Fig. 5 Release of Birefringence with time at a constant temperature.

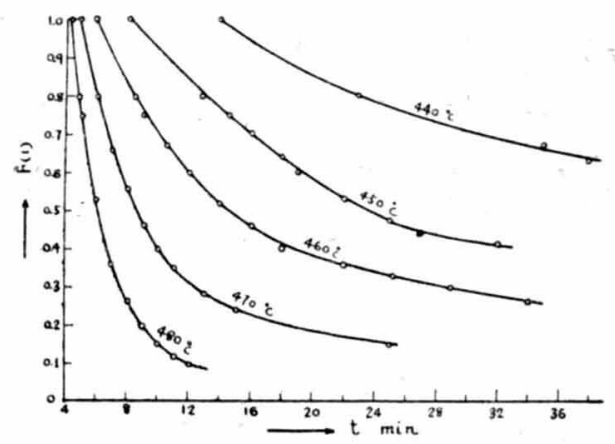

Fig. 6 Release of Strain $\bar{F}(1)$ (birefringence at $x / a=1)$ at various Temperatures. Measures were taken after $\bar{F}(1)=1$.

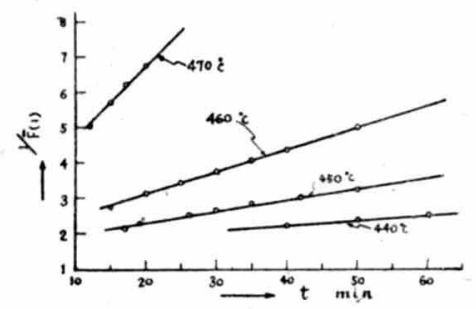

Fig. 7 Release of Chemical Strain at various Temperatures.

アル障壁の高さ $\triangle F^{*}$ を計算することができる。 その值は約 $83 \mathrm{kcal} / \mathrm{mol}$ である。

(ii) Mechanical Process 比較的大きな雷が初 期の段階において急速に緩和されるのは Chemical Processに Mechanical Process か湩畳して起る為で 
Fig. 6 とFig.7 から, Mechanical Process のみを分 離すると Fig. 9 のように Maxwell の一次式(7)に従

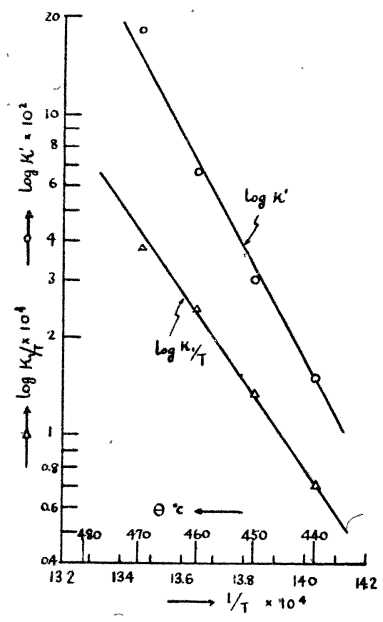

Fig. 8 Temperature Dependence of $K_{1} / T$ and $K^{\prime} . K_{1}$ and $K^{\prime}$, the reaction rate constants, follow Maxwell's first Law and Adams-Williamson's Law respectively.

らことが知れる。こ の過程は, 各構造単 位内至解離体力独立 にFig. 2 の非対称ポ テンシアル障壁を越 えることにより，そ の内部応力による強 制配列を解く過程で あり，(7) 式の反応 速度恒数 $K_{1}$ が Fig 8 のような温度依存 性を持つので，(8) 式の障壁の高さ $\triangle F_{1}$ * を計算するこ とができる。すなわ ち, $\triangle F_{1}^{*}=58 \mathrm{kcal} /$ mol. となる。

5. 総括

一定温度における birefringence の緩

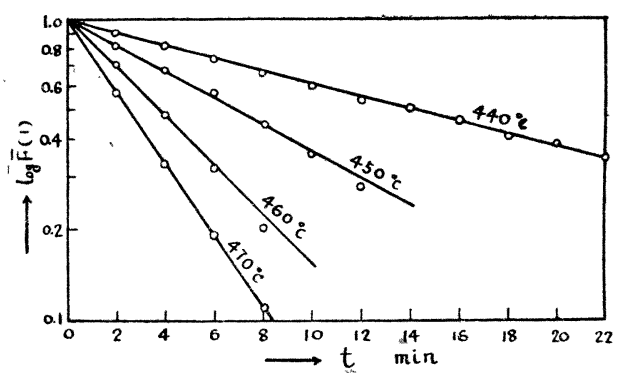

Fig. 9 Release of Mechanical Strain at various Temperatures.

和過程を観察し, その機構が異なつた二つの過程, 即 ち Maxwel1-則に従う mechanical strain の除去と Adams Williamson 則に従弓 chemical strain の 除去との二つによつて為されることを確めた。高温 （実験に供したガラスでは $480^{\circ} \mathrm{C}$ 以上)では化学的な 平衡条件が急速に再現されるので, 歪の除去は Maxwell 則のみに従 ${ }^{99}$ 。

陶磁器鑑賞講演会 6 月 10 日午後 2 時上り東京上 野公園の国立博物館小講堂で文化财専問鱕議会委員小 山富士夫氏によつて「日本の陶器とピカソの陶器」と 題乙て講演会を開いた。水地講濱理事の「日本の陶磁 器の優秀性, さらに材質の優秀性はデザインの良否に よつて商品の価値字決定する。現下の業界で要望され るものは永遠化新鮮さを失 5 ととない芸術味豊かな
異なつた二つの除昰過程は, Eyring 模型によつて 説明できる。不飽和解離体の平行配列内至構造単位間 の結合手に与えられた歪の除去は, 非対称ポテンシア ル障壁をもつ Maxwell 過程に彷い, その障壁の高さ は $5.8 \mathrm{kcal} / \mathrm{mol}$. である。更に, 強制配列を解かれた 不飽和解離体は $83 \mathrm{kcal} / \mathrm{mol}$ の山を越えて相会合し, Adams-Williamson 過程を実現する。化学的に平衡 にある場合のガラスの粘弾性的挙動（例えば遅れ弾性 余効 ${ }^{10)}$ 等) は，すべて Maxwe11 式に従い，この場 合の模型は対称ポテンシアル障壁のみを考慮すればよ い。しかし, Weyl 11) の述べているようにガラス内 の除雪現象が Maxwell 式に従うか AdamsWilliamson 式に従らかは単に見掛上の問題であつて 除歪は恐らく Maxwell 式に従つて行われるもので あろらが, 除歪中にガラスの光弾性常数, 粘度, 緩和 時閒等が連続的に変化する結果, Maxwêll 式からは ずれてくるのであろう。最近 $\operatorname{Cox}{ }^{12)}$ は新しい除胥 式として $\log f / f_{0}=a t+b \log (1+c t)$ を提唱し, 実験的 に $a, b, c$ を決定している。

擱筆するに当り種々御指導, 激励を賜つた当社技術 部長有住做彌博士に厚く感謝の意を表す。

\section{交献}

（I）北野，筌協学術講演会において発表，(昭和26年 10月)

(2) N. W. Táylor, J. Am. Cercm.Soc., 21, 85 (1938)

(3) J.C. Maxwe11, Fhil. Mag., 35, 134 '(1867)

(4) L.H. Adams, E. D. Williamson, J. Frank. Inst., 190, 597(1920)

(5) Glasstone, Laidler, and Eyring, The Theory of Rate Processes. (Mcgraw-Hill Book Co. 1940)

（6）森谷・佐藤，筧協学術講演会汇おける講演（昭和 26 年 4 月)

(7) H. Eyring, J.Chem. Phys., 3, 107 (1935)

(8) F.W. Cagle, H. Eyring, J. App. Phys., 22 771 (1951)

(9) J. Bailey, D.E. Sharp, J. Am. Ceram. Soc., 16, 367 (1933)

(10) N. W. Taylor, E. P. McNamara, J. Shearman, J. Soc. glass Tech., 21, 61 (1937)

(11) W.A. Weyl, J. App. Phys., 14, 37 (1943)

(12) S.M. Cox, J. Soc. glass Tech., 32, 340 (1948) (12/28/51 受附)

デザインであ」るとの挨拶と講師の紹介があつて，同 2 時 20 分より上記演題のすとに幻灯走使つて約 1 時間 半にわたり興味深い講演が行われた。本謢演は一般飞 も開放したので出席者も50 名四多き達し, 珍しく 女性の姿も 10 名余学数えた。本講演の速記録は 9 月 号代掲載の予定で目下整理中である。 